\title{
Cumhuriyet Dönemi Türk Tiyatrosunda Doğa ve Ormana İlişkin Yaklaşımların İrdelenmesi
}

\author{
Buğra Kağan KAHRAMAN ${ }^{1}$, Seçil YURDAKUL EROL ${ }^{1 *}$ \\ ${ }^{1}$ İstanbul Üniversitesi-Cerrahpaşa, Orman Fakültesi, Orman Mühendisliği Bölümü, 34473, Bahçeköy- \\ Sarıer/İstanbul
}

Öz

Kişilerin ve toplumların gelişiminde etkili bir rol oynama potansiyeline sahip olan tiyatro bir bilinçlendirme ve eğitim aracı olarak değerlendirilebilmektedir. Bu çerçevede çalışmada, Türkiye'de Cumhuriyetin ilanından günümüze, İstanbul Şehir Tiyatrolarında repertuvara alınmış ve sahnelenmiş olan yerli ve yetişkinlere yönelik tiyatro eserlerinde, doğa ve ormanla ilgili unsurlar içerik analizi yöntemiyle değerlendirilmiştir. Araştırma sonucunda, ana ve yan teması doğa ve orman olan eserlerin yok denecek kadar az olduğu, örneklem kapsamına giren tiyatro eserlerinde de doğa ve ormana ilişkin içeriklerin çok sınırlı düzeyde kaldığı belirlenmiştir. İncelenen eserlerde doğa ve ormanla ilgili içeriklerin, çoğunlukla ağaç, su, nehir, kuş, geyik, yaprak gibi ormanı oluşturan ve çağrıştıran unsurlar kategorisinde olduğu görülmüştür. Ormancılıkla ilgili etkinlikler ve ormanların işlevleri içerik olarak çok daha az bulunmaktadır. Ulaşılan bulgular ışığında doğa ve ormanla ilgili olarak toplumda farkındalık oluşturabilecek eserlerin yazılması ve sahnelenmesinin teşvik edilmesi, çok disiplinli bir yaklaşımın ilgili eğitim süreçlerinde benimsenmesi, kurumsal işbirliklerinin geliştirilmesi kapsamında bazı yaklaşımlar ortaya konulmuştur.

Anahtar Kelimeler: Orman, doğa, tiyatro, İstanbul Şehir Tiyatrosu, içerik analizi.

\section{Investigation of Approaches Regarding Nature and Forest in Turkish Drama in the Republic Period}

\begin{abstract}
Theater, that has the potential to play an effective role in the development of individuals and societies, can be considered as a tool of awareness and education. The content relevant to nature and forest was investigated in the context of drama texts which were written by domestic authors at Republican period and staged by Istanbul City Theatre by content analysis method. It was determined that there is almost no drama text in which the main and sub-themes are related with nature and forest and also the related content of in the sampled texts is very limited. The results of the research revealed that the nature and forest contents of in the sampling texts were mostly in the category of "elements that consists and associated with forest" such as trees, water, rivers, birds, deer, leaves. Forestry-related activities and functions of forests have much less content. In the light of the findings, suggestions were made to encourage the writing and staging of drama that could raise awareness about nature and forests, adopting a multidisciplinary approach in related educational processes, developing institutional and individual collaborations.
\end{abstract}

Keywords: Forest, nature, drama, Istanbul City Theatre, content analysis. 


\section{Giriş}

Tiyatronun kavramsal olarak çeşitli tanımları bulunmakla birlikte Yunanca' da "seyirlik yeri" anlamına gelen "theatron" kelimesinden türetildiği bilinmektedir (Şener, 2006). Bu konudaki tanımların temelini Aristoteles'in Poetika'da tiyatronun özünde oyun olduğunu vurguladığı yaklaşım ile bu kapsamda oyun oynamanın insanın doğasında bulunduğunu belirtmesi oluşturmaktadır (Tunalı, 1995). Yılmaz (2017) tiyatronun insanlık tarihi kadar eski olduğunu ortaya koymuş ve "insandan insana dolaysız iletişim kurabilen tek sanat" olarak tiyatroyu tanımlamıştır. Gürün (2009) tiyatroyu; sınır, ırk, din, cinsiyet vb. farklılıkların ötesinde gerçek hayat olarak değerlendirmektedir. Bu yaklaşıma paralel olarak tiyatro "çeşitli işlevleri bünyesinde barındıran bir değerler bütünü” olarak tanımlanmakta ve bu kapsamda özellikle toplumu eğlendirirken eğitme işlevine vurgu yapılmaktadır. Fuat (2000) tiyatro kavramını oluşturan unsurları; i. oyuncular; ii. seyirci yeri, sahne, dekor, giysi, ışık, ya da bunlardan birkaçı ve iii. seyirci olarak sıralamış ve karışık, çok yönlü bir sanat olarak nitelemiştir.

Tiyatronun işlevleri; önceleri izleyicileri etkileme gücü, hoşlanma duygusu, estetik algısı ile ahlak eğiticiliği kapsamında ele alınmıştır (Şener, 2006). Daha geniş çerçevede bakıldığında bu işlevler; seyirciyi bilinçlendirmek, duyarlığını artırmak, eğlenme ve haz almasını sağlamak ile ileriye doğru yöneltmek olarak ortaya çıkmaktadır (Şener, 1972; Brecht, 1993). Yine toplumsal açıdan tiyatronun işlevleri; toplumu uyarma, yol gösterme, toplumsal alg1 oluşturma şeklinde sıralanmaktadır (Keskin, 2008; Güney, 2011; Temel, 2016).

Söz konusu işlevlerin değişimi, gelişimi ve çeşitlenmesi tiyatronun tarihsel gelişimiyle de ilişkilidir. $\mathrm{Bu}$ kapsamda tiyatronun tarihi Eski Yunan ve Antik Misır'a dayanmaktadır. Ancak tiyatronun on binlerce yıllık geçmişi olduğu düşünülmektedir. Mağara duvarlarındaki hayvan kostümlü insan figürleri bu çerçevede ipucu vermekle birlikte tiyatronun mitoloji ve ritüellerden doğduğu düşünülmektedir (Fuat, 2000; Brockett and Hildy, 2017). Ancak tiyatro konusundaki ilk kuramsal yaklaşımlar, Antik Yunan uygarlı̆̆ına dayanmaktadır. Tragedya ve Komedya türlerinde baş eserler sanat ve kültür açısından en parlak dönem olarak değerlendirilen Klasik Çağ'da ortaya çıkmış, böylelikle ilkel törenlerde görülen büyü ve sihir gibi unsurlar yerine çağdaş düşünce öne çıkmıştır (Şener, 2006). Roma döneminde gelişimi duraksayan Orta Çağ'da ise kilise baskısı altında kalan tiyatro, 15. ve 16. yüzyıllarda Rönesans'nn etkisiyle gelişme göstermiştir (Brockett and Hildy, 2017; Şener, 2006).

17. ve 18. yüzyıllarda klasik tiyatro anlayışı egemen olmuş, sanat çalışmaları desteklenmiş ancak tiyatro üzerinde sarayın gözetim ve denetimi artmıştır (Şener, 2006). 18. yüzyılda Fransız Devrimi'nin (1789) de etkisiyle ulusalcılık, duygusallık ve özgürlük unsurları tiyatro sanatı içinde yer bulmaya başlamış, romantizm akımının etkisi artış göstermiştir (Keskin, 2008). 19. yüzyılın 2. yarısında romantik tiyatroya karşı gerçekçi akım gelişmiş, dönemin sosyolojik sorunlarına odaklanmak ve bu sorunları bilimsel olarak değerlendirmek esas alınmıştır (Fuat, 2000). 19. yüzyıl sonlarında oyun yazarları realizm akımına paralel olarak çeşitli modern akımların etkisiyle eserler üretmiştir (Nutku, 1963). 20. yüzyılda epik tiyatro anlayışı gelişmiş; izleyicinin konuyu irdelemesini, düşünmesini ve tartışmasını sağlamaya yönelik yaklaşımlar sergilenmiştir. İzleyen dönemde, yaşanan savaşların da etkisiyle uyumsuzluk tiyatrosu olarak isimlendirilen; insanlığın yaşadığı saçmalıkları, umut ve acıları konu edinen tiyatro akımı baş göstermiştir. Savaşların sona ermesi, yasakların kalkması, küreselleşmenin hızlanması ve toplumlar arasındaki kültürel ilişkilerin gelişmesinin etkisiyle tiyatroda çok farklı yaklaşımlar oluşmuştur. Çok sayıda akım gelişmiş, modern sanat ve tiyatro denemeleri hızlı şekilde artış göstermiştir. 1960'lardan sonra tiyatro anlayışı özgürlük yaklaşımıyla şekillenmiştir (Nutku, 1963).

Tüm bu süreç tiyatro ile insan arasında sadece sahnede değil, sosyolojik olarak derin bir bağ olduğunu göstermektedir (Kılıç, 2011). Kuşkusuz tiyatronun insan ve toplum üzerindeki etkileri doğa ile ilgili konularda da geçerlidir. İlkel toplumlarda doğanın gizemini tanımak için sanat bir araç olmuştur. Antik Yunan ve Yakın Doğu kültürlerinde mevsim geçişlerinde oynanan oyunlar mitleşmiş, öyküleşmiş ve günümüze kadar gelmiştir (Şener, 2006). Av, yağmurun yağması, ürünlerin çoğalması, büyüme ve üreme törenlerinde doğa taklitleri yapılmıştır (Fırat, 2000). Bu derece doğa ile iç içe olan insanın, taklitle ritüellerden tiyatroya ulaştığı görülmektedir.

Doğa, tiyatronun doğuşunda temel esin kaynağı olduğu gibi, çağdaş tiyatroda özellikle pek çok oyunda mekânsal açıdan öne çıkmaktadır (Çalışlar, 2009). Bununla birlikte tiyatro sahnesinde de doğa ile ilgili unsurların sıklıkla yer aldığı görülmektedir. Kuşkusuz tiyatro oyunlarının içeriğinde de doğa ile ilgili unsurlar yer bulmaktadır. $\mathrm{Bu}$ şekilde tiyatro aracıllğıyla izleyiciye doğayla ilgili mesajlar vermek mümkündür. Belirtilen çerçevede insan ve doğa arasındaki çatışmayı ele alan Heim (2016), bu durumu tiyatronun hammaddelerinden biri olarak değerlendirmekte ve tiyatroda konu edinilmesi gereken öncelikli yaklaşımlar arasında görmektedir. İlgili anlayışa paralel olarak çevreye verilen zarar ve bu zararın insan ve doğaya olan olumsuz etkileri hakkında bilinç oluşturmaya yönelik olarak çevreci eleştiri (eko-eleştiri) yaklaşımı gelişmiştir. Söz konusu yaklaşım kapsamında çevreye verilen zarar ile oluşacak etkiler hakkında insanları bilgilendirme, bilinç ve farkındalık oluşturmaya 
çalışılmakta, bunu duygular aracılığıyla insanlara iletme yolu seçilmektedir (Ayaz, 2014; İgit, 2017; Şen, 2018). Belirtilen akım edebiyat, resim, sinema gibi pek çok yazılı ve görsel sanat dalında etkisini göstermeye başlamıştır. Tiyatroda da uluslararası alanda çevreci eleştiri kapsamında eserler üretildiği bilinmektedir. Anlaşıldığı üzere çevre ve doğaya ilişkin unsurlar modern tiyatroda da etkisini göstermekte ve oyun içeriklerinin oluşturulmasındaki yeri giderek artmaktadır.

Genel olarak değerlendirildiğinde doğa hem tiyatronun gelişimi açısından etkili bir rol oynamış hem de tiyatronun önemli bileşenlerinden biri olmuştur. Yani doğa tiyatronun hem amacı hem aracı olarak işlev görebilmekte, aralarındaki ilişki ve etkileşim tiyatro tarihi kadar eskilere dayanmakta ve sürekliliğini korumaktadir.

Belirtilen çerçevede çalışmanın amacı; Türkiye'de Cumhuriyetin ilanından günümüze kadar yazılmış ve sahnelenmiş olan, yetişkinlere yönelik tiyatro eserlerinde doğa ve ormanla ilgili içerikleri irdelemek ve öne çıkan konuları analiz etmektir. $\mathrm{Bu}$ amaç doğrultusunda Türk tiyatro eserlerinde doğaya ve ormana ne şekilde yer verildiği, ne tür ifadeler kullanıldığı ve sözü edilen eserlerde hangi içerikte mesajlar olduğu araștırma konusunu oluşturmaktadır. Diğer taraftan, ormancılığın geçmişten beri önemli sorunlarından biri olan halkla ilişkiler çalışmalarına yönelik eksikliklerin giderilmesine yardımcı olacak sonuçlara ulaşılması da amaçlanmıştır. Belirtilen amaçlara ulaşmak için çalı̧̧ma, İstanbul Şehir Tiyatroları tarafından sergilenen ve repertuvara alınan eserler kapsamında gerçekleștirilmiștir.

\section{Materyal ve Metot}

Çalışmanın esas materyalini İstanbul Şehir Tiyatroları arşivinde bulunan, sahnelenen ve repertuvardan geçen, Türk yazarlar tarafindan yazılan oyunlar oluşturmuştur. Çalışmada temel veri toplama ve değerlendirme yöntemi olarak İçerik Analizinden yararlanılmıştır. Yöntem olarak İçerik Analizi hem veri toplama hem de toplanan verilerin analizi ile ilgili aşama ve süreçleri içermektedir. Belirtilen yöntem; yazıll, görsel ve sözlü dokümanların tema, anlam ve mesajlarını belirlemek amacıyla yararlanılan, ilgili dokümanın ayrıntılı, dikkatli ve sistematik olarak değerlendirilmesini gerektiren bir yöntemidir (Berg and Lune, 2015). Temelde belirtilen yöntemden, üzerinde araştırma yapılan dokümanda yer alan ve tekrarlanan içerikleri tarafsız olarak değerlendirmek ve geçerli olan çıkarımları belirli kural ve süreçler dahilinde yapmak amacıyla yararlanılmaktadır (Krippendorff, 1980; Prasad, 2008). Diğer bir deyişle, hakkında çalışılan belgenin nitel ve nicel açılardan değerlendirilerek bilinmeyen veya açıkça görülemeyen boyutlarına ilişkin bulgulara ulaşmaya yarayan bir yöntem olarak tanımlanmaktadır (Gökçe, 2006).

Genel olarak tanımdan da anlaşılacağı üzere İçerik Analizi yönteminin amaçlarını; iki başlık altında toplamak mümkündür. Bu amaçlar; metinler veya dokümanlar hakkında sistematik veri elde etmek, üzerinde çalışılan metin veya dokümanlarda saklı olan anlam ve boyutları belirlemek ve bunlara ilişkin çıkarımlar yapmaktır (Bilgin, 2006; Gökçe, 2006). Yönteme uygun şekilde araştırma süreci aşağıdaki şekilde gerçekleşmiştir. Sürecin tasarlanmasında yönteme ilişkin kaynak ve ormancılık alanında belirtilen yöntemi kullanarak yapılan bazı araştırmalardan yararlanılmıştır (Stemler, 2001; Bilgin, 2006; Gökçe, 2006; Berg and Lune, 2015; Yurdakul Erol, 2018; Yurdakul Erol ve Yıldırım, 2017; Yurdakul Erol ve Şahin, 2016):

Araştırma soru ve amacının belirlenmesi: Çalışmanın amacı; Türk tiyatrosunda yerli yazarlar tarafından yazılan ve sahnelenen metinlerde orman ve doğa ile ilgili unsurları ve içerikleri değerlendirmek ile verilen mesajları irdelemektir.

Örneklemin belirlenmesi: Araștırma evreni 1916 ve 2017 yılları arasında İstanbul Sehir Tiyatroları tarafindan sahnelenen ve repertuvara alınan 570 yerli ve yetişkin oyunundan oluşmuştur. Belirtilen kapsamdaki oyunlar arasında örneklem seçiminde bilinçli (tesadüfi olmayan veya kasti) örnekleme yönteminden yararlanılmıştır. Bu tür örneklemede, örnekleme girecek birimler araştırmacının veya ilgili uzmanların sübjektif yargısına bağlı olmakta yani deneklerin belirlenmesindeki ölçüt yargısal yaklaşımlar olarak ortaya çıkmaktadır (Coşkun ve ark., 2015). Dolayısıyla denekler rastgele seçilmemekte ve örneklem, araştırma konusuna uygun olarak belirlenen birimlerden oluşturulmaktadır.

Örneklem seçiminde; İstanbul Şehir Tiyatroları ve İstanbul Devlet Tiyatroları Dramaturgi Birimlerinde görev yapan bazı çalışanlar ile İstanbul Üniversitesi Edebiyat Fakültesi Tiyatro Eleștirmenliği ve Dramaturgi Bölümü, İstanbul Üniversitesi-Cerrahpaşa Orman Fakültesi ve Çankırı Karatekin Üniversitesi Orman Fakültesi'nde görevli bazı öğretim elemanlarından görüş alınmıştır. Bu noktada öncelikli olarak ana teması orman ve doğa olan eserler ile ana tema olmasa bile konu ve kapsamında orman ve doğa unsurlarının yer aldığı oyunlara ilişkin 
bilgiler elde edilmiştir. $\mathrm{Bu}$ çerçevede örnek eserlerin belirlenmesindeki temel yaklaşım; doğa ve orman hakkındaki en kapsamlı tiyatro metinlerinde konunun işlenişi ve yapılan vurgular hakkındaki bilgileri ortaya koyabilmek olmuştur. Belirtilen uzmanların görüşleri doğrultusunda ortaya çıkan tüm eserler kapsamında irdeleme yapılmıştır. Söz konusu oyunlar ve bu oyunlara ilişkin genel bilgiler aşağıda verilmiştir.

Binali ile Temir, Murathan Mungan tarafından kaleme alınmış, “Cenk Hikayeleri” kitabında 1986'da yayımlanmıştır. Sahneye uyarlayan ve yöneten Yıldırım Fikret Urağ tarafindan 2009-2010 sezonunda 2 perde olarak sahnelenmiştir. Oyuncular; Haldun Ergüvenç, Yıldırım Fikret Urağ, Gün Koper ve Ushan Çelebi’dir. Binali ile Temir, bir eşkıya ile çoban arasında geçmekte ve bu ikilinin yaşadığı çatışmayı anlatmaktadır.

Divane Ağaç eserinin yazarı Turgay Nar'dır ve ilk olarak 2006 yılında yayımlanmıştır. 2007-2008 ve 2008-2009 yıllarında 2 sezon olarak Hüseyin Köroğlu yönetmenliğinde sahnelenmiştir. Oyuncular; Erhan Abir, Tomris İncer, Zümrüt Erkin, Meriç Benlioğlu, Çağlar Yiğitoğulları, Eraslan Sağlam, Esin Umulu, Pelin Budak ve Özge Midilli'dir. Divane Ağaç, ritüeller ile tasavvuf bakış açılarını ağaç ile ele alan bir oyundur.

Susuz Yaz eseri Necati Cumalı tarafından 1960 yılında 3 perdelik oyun olarak yazılmıştır. Eser, Metin Erksan tarafından 1963 yılında filme çekilmiş ve bir yıl sonra 1964'te 14. Uluslararası Berlin Film Festivalinde altın ayı ödülünü alarak Türk sinemasında çığır açmıştır. Kemal Bekir yönetmenliğinde 1967-1968 ve 1983-1984 yıllarında sahnelenmiş olan oyun, köyde haneler arası çıkan su çatışmasını anlatmaktadır.

Ormanda eseri Cahit Atay tarafından 1964 yılında kaleme alınmıştır. Eser 1964-1965 sezonunda Hamit Akınlı yönetiminde, Feridun Karakaya, Fuat İşhan ve Oral Yonci oyunculuklarıyla sahnelenmiştir. Ormanda, arazi yetersizliğinden tarla açan iki köylünün korucuya yakalanması ve aralarındaki ilişkiler ile komik mesaj içeren diyaloglardan oluşmaktadır.

Içerik kategorilerinin belirlenmesi: Çalışma kapsamında iki temel içerik kategorisi oluşturulmuştur. Bunlar: "Ormanı ve doğayı oluşturan ve çağrıştıran unsurlar" ile "Ormanlarla ilgili etkinlikler ve ormanların işlevleri" olarak belirtilebilir. Söz konusu kategoriler kapsamında değerlendirilen unsurlar Şekil 1'de görülmektedir.

Kategoriler ve içerikler belirlenirken, tiyatro metinlerinde rastlanılması olası kavramlar ve bileşenler dikkate alınmıştır. "ormanı ve doğayı oluşturan ve çağrıştıran unsurlar” kategorisinde yer alan ifadeler, çeşitli orman tanımlarında geçen ağaç, ağaççık çalı, otsu bitki, arazi, toprak, hava, hayvan gibi unsurların yanı sıra yeşil, doğal çevre, kök, koru, gibi konuyla ilişkisi bulunan ve yaygın kullanımı olan terimlerden oluşturulmuştur. Belirtilen kategoride 14 unsura yer verilmiştir. "Ormanlarla ilgili etkinlikler ve ormanların işlevleri” kategorisinde ise ormanların ürettiği çevresel, ekonomik ve sosyal hizmetler kapsamında yer alan işlevler yer bulmuştur. Ayrıca ağaçlandırma, odunculuk, avcılık, kaçakçılık gibi halk tarafından bilinen ve ormancılıkla ilişkili konular bu kategoride değerlendirilmiş ve bu yolla 21 unsur belirlenmiştir. Söz konusu çerçevede ormancılık tekniği ile ilgili amenajman, orman hasılatı gibi kavramlar kapsam dışında tutulmuştur. Bununla birlikte kategori sistemi içinde yer almayan ancak çalışma konusuyla ilgili ifadeler ise değerlendirmeye alınmıştır. Örneğin ağaç ve bitki türü isimleri ile yaban hayatı örnekleri ilgili olduğu kategoriler içerisinde değerlendirilmiştir. Bununla birlikte sistem içerisinde yer alan ancak orman ve doğayla ilişkili olmayan bir anlamda kullanılan ifadeler de değerlendirme dışı tutulmuştur. Yeşil kazak veya bir çocuğun annesi tarafından korunması gibi ifadeler bu kapsamda örnek olarak verilebilir.

Kod (içerik) birimlerinin belirlenmesi: Kod birimleri olarak cümleler seçilmiş, böylelikle cümle içi tekrarlar dikkate alınabilmiştir. Diğer bir ifadeyle, aynı cümle içerisinde birden fazla kez geçen benzer ifadeler sonucun yanıltıcı olmaması açısından bir kez sayılmıştır. Bununla birlikte değerlendirilecek kelime ve ifadeler belirlenmiş, her birimin kategorilerle ilişkisi dikkate alınmıştır.

Verilerin analiz edilmesi: Kod birimlerinin değerlendirilmesinde frekans değerleri dikkate alınmış, böylelikle her bir kategori ve unsurun metin içinde bulunma sıklığı belirlenmiştir. Ayrıca, her bir kategori ve unsurun ayrı ayrı oyun metinleri içinde rastlanma sıklığı ile tüm metinler içerisinde yer alma sıklığı yüzde olarak değerlendirilmiştir. Bunun dışında her eserde rastgele seçilen beş sayfada toplam kaç kelime olduğu tek tek sayılarak ve daha sonra ortalamaları alınarak, sayfa başı ortalama kelime sayıları hesaplanmıştır. Bulunan bu ortalama (bir sayfadaki kelime sayısı) ile eserin toplam sayfa sayısı çarpılarak eserdeki toplam kelime sayısı yaklaşık olarak hesaplanmıştır. Eserde bulunan içerik unsur ve kategorilerinin frekans değeri ile eserin toplam kelime sayısı karşılaştırılarak ilgili unsurun metin içinde bulunma oranı hakkında bilgi elde edilmiştir.

İçerik analizi yapılırken, eserler okunmuştur. Eserlerde içerik analizleri metin içinde geçme durumuna göre üç kategoride ayrı ayrı ele alınmıştır. Bunlar; i. betimleme: diyalog ve karakterler harici olay döngüsünü anlatmada 
yardımcı olacak açıklamalar, ii. kişileştirme: karakter isimleri olarak geçen içerikler, iii. diyalog: karakterlerin eserde söyledikleri kelimeler olarak belirlenmiştir.

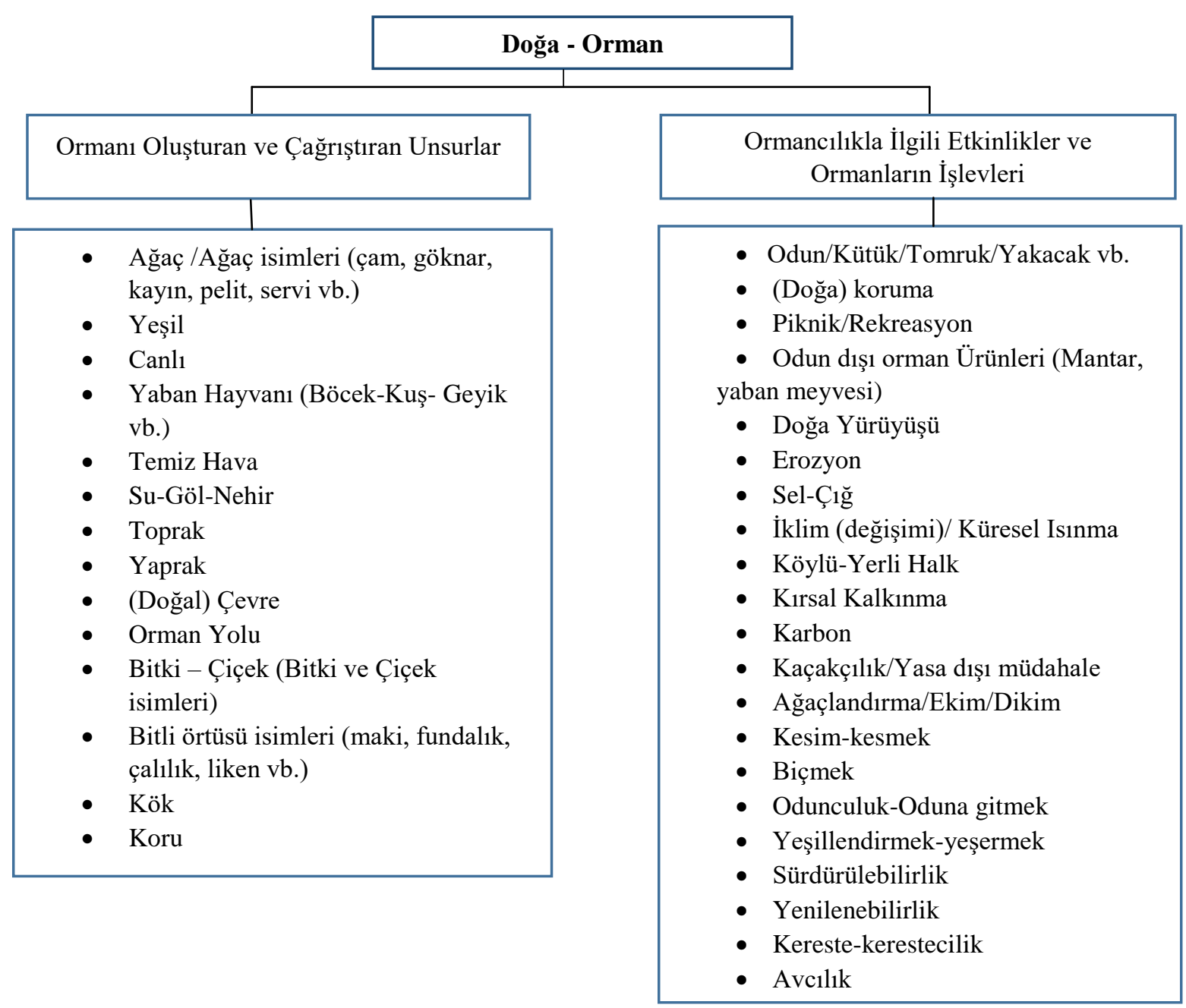

Şekil 1. Orman ve doğa ile ilgili içerik kategorileri ve unsurları.

\section{Bulgular}

Araştırma örneklemi olarak belirlenen 4 eser, içerik kategorilerine ve unsurlarına göre analiz edilmiştir. Belirlenen unsurların oyunda ne şekilde geçtiği, frekansı, toplam ifadeler içindeki yüzdesi Tablo 1'de, içerik kategorilerinin bulunma şekli ise Tablo 2'de verilmiştir. "Binali ve Temir", "Divane Ağaç", "Susuz Yaz" ve " Ormanda" adlı oyunlara ilişkin içerikler bu bölümde ayrı ayrı incelenmiştir.

\subsection{Binali ve Temir}

"Binali ile Temir" adlı eserde belirlenen iki temel kategori altındaki pek çok unsura ilişkin içerik bulunmamaktadır. "Ormanı oluşturan ve çağrıştıran unsurlar" kategorisinde bulunan 14 unsurdan 5'i, "ormancılıkla ilgili etkinlikler ve ormanların işlevleri”" kategorisinde yer alan 21 unsurdan 15'ine ilişkin ifade bulunmamaktadır. Frekans değeri yüksek olan yani metin içinde daha çok yer alan unsurlar, kategori olarak “ormanı oluşturan ve çağrıştıran unsurlar" kapsamında yer almaktadır ( $\mathrm{f}=209)$. "Ormancılıkla ilgili etkinlikler ve ormanların işlevleri” kategorisinde bulunan unsurlara metin içinde az sayıda (f=15) rastlanmıştır (Tablo 1).

İlgili metinde "ormanı oluşturan ve çağrıştıran unsurlar" kategorisinde yapılan içerik analizinde frekansı en yüksek olan unsur ( $\mathrm{f}=72, \% 32.14$ ) "yaban hayvanı" olmuştur. Aynı kategoride yer alan unsurlar içinde bulunma sıklığı sırasıyla orman ( $\mathrm{f}=44, \% 19.64)$, ağaç $(\mathrm{f}=28, \% 12.5)$, bitki örtüsü isimleri ( $\mathrm{f}=19, \% 8.48)$, bitki-çiçek ve isimleri ( $\mathrm{f}=16, \% 7.14)$ ile ilgili unsurlar şeklindedir. "Ormancılıkla ilgili etkinlikler ve ormanların işlevleri" 
kategorisi incelendiğinde ise avcılık ( $\mathrm{f}=6, \% 2.68)$ ve köylü (yerli halk) ( $\mathrm{f}=5, \% 2.23$ ) ile ilgili unsurların en sık rastlanan ifadeler olduğu belirtilebilir.

Genel bir değerlendirme yapıldığında Binali ve Temir adlı eserde orman ve doğaya ilişkin yer alan ifadelerin büyük çoğunluğu ( $\mathrm{f}=209$, \%93.30) "ormanı oluşturan ve çağrıştıran unsurlar" kategorisinde bulunmaktadır. Tablo 2'de görüldüğü üzere tüm unsurlar için bir değerlendirme yapıldığında büyük çoğunluğunun (f=159, \%70.98) betimleme şeklinde yer aldığı görülmektedir. Metindeki içerik açısından ilgili unsurların diyalogda geçme oranı \%19.64 ( $\mathrm{f}=44)$ iken, kişileştirmelerde bulunma \%9.38 ( $\mathrm{f}=21$ ) düzeyindedir (Tablo 2).

Tablo 1. "Binali ve Temir", "Divane Ağaç", "Susuz Yaz” ve "Ormanda” eserlerinde orman ve doğa ile ilgili içeriklerin analizi

\begin{tabular}{|c|c|c|c|c|c|c|c|c|}
\hline \multirow[t]{2}{*}{ Tiyatro Eseri } & \multicolumn{2}{|c|}{$\begin{array}{c}\text { Binali ve } \\
\text { Temir }\end{array}$} & \multicolumn{2}{|c|}{ Divane Ağaç } & \multicolumn{2}{|c|}{ Susuz Yaz } & \multicolumn{2}{|c|}{ Ormanda } \\
\hline & $\mathbf{f}^{*}$ & $\%^{* *}$ & f & $\%$ & f & $\%$ & f & $\%$ \\
\hline Ağaç & 28 & 12.5 & 67 & 27.01 & 12 & 7.89 & 52 & 20.71 \\
\hline Yeşil & - & - & - & - & 1 & 0.66 & 1 & 0.39 \\
\hline Canlı & - & - & - & - & - & - & - & - \\
\hline Yaban Hayvanı & 72 & 32.14 & 85 & 34.27 & 16 & 10.52 & - & - \\
\hline Temiz Hava & 1 & 0.45 & - & - & - & - & - & - \\
\hline Su-Göl-Nehir & 7 & 3.13 & 32 & 12.90 & 91 & 59.86 & - & - \\
\hline Toprak & 10 & 4.46 & 16 & 6.45 & 7 & 4.61 & 9 & 3.58 \\
\hline Yaprak & 11 & 4.91 & 4 & 1.61 & 4 & 2.63 & - & - \\
\hline (Doğal) Çevre & 1 & 0.45 & - & - & - & - & 1 & 0.39 \\
\hline Orman (Yolu vb.) & 44 & 19.64 & - & - & - & - & 36 & 14.34 \\
\hline Bitki-Çiçek & 16 & 7.14 & 15 & 6.04 & 10 & 6.58 & 1 & 0.39 \\
\hline Bitki Örtüsü & 19 & 8.48 & 3 & 1.20 & 3 & 1.97 & - & - \\
\hline Kök & - & - & 20 & 8.06 & - & - & 5 & 1.99 \\
\hline Koru & - & - & - & - & - & - & 6 & 2.39 \\
\hline $\begin{array}{l}\text { TOPLAM (Ormanı Oluşturan ve } \\
\text { Çağrıştıran Unsurlar) }\end{array}$ & 209 & 93.3 & 242 & 97.59 & 144 & 94.74 & 111 & 44.18 \\
\hline Odun, Kütük, yakacak vb. & 2 & 0.89 & - & - & - & - & 1 & 0.39 \\
\hline Doğa Koruma & - & - & - & - & - & - & 82 & 32.67 \\
\hline Piknik/Rekreasyon & - & - & - & - & - & - & - & - \\
\hline Odun Dıı̧1 Orman Ürünleri & - & - & - & - & - & - & - & - \\
\hline Doğa Yürüyüşü & - & - & - & - & - & - & - & - \\
\hline Erozyon/Sel/Çığ & 1 & 0.45 & - & - & - & - & - & - \\
\hline İklim Değişimi & - & - & - & - & - & - & - & - \\
\hline Köylü/Yerli Halk & 5 & 2.23 & - & - & 6 & 3.95 & 8 & 3.18 \\
\hline Kırsal Kalkınma & - & - & - & - & - & - & - & - \\
\hline Karbon & - & - & - & - & - & - & - & - \\
\hline Kaçakçılık/Yasa Dışı Müdahale & - & - & - & - & 1 & 0.66 & 7 & 2.78 \\
\hline Ağaçlandırma/Ekim/Dikim & - & - & - & - & - & - & - & - \\
\hline Kesim/Kesmek & - & - & - & - & - & - & 33 & 13.14 \\
\hline Biçmek & - & - & - & - & - & - & - & - \\
\hline Odunculuk/Oduna Gitmek & 1 & 0.45 & - & - & - & - & 6 & 2.39 \\
\hline Yeşillendirmek/Yeşermek & - & - & - & - & - & - & - & - \\
\hline Sürdürülebilirlik & - & - & - & - & - & - & 1 & 0.39 \\
\hline Yenilenebilirlik & - & - & - & - & - & - & - & - \\
\hline Kereste/Kerestecilik & - & - & - & - & - & - & 1 & 0.39 \\
\hline Yangın (Orman/Doğal) & - & - & 4 & 1.61 & - & - & 1 & 0.39 \\
\hline Av-Avcılık & 6 & 2.68 & 2 & 0.81 & 1 & 0.66 & - & - \\
\hline TOPLAM (Ormancılıkla ilgili & 15 & 6.70 & 6 & 2.41 & 8 & 5.26 & 140 & 55.72 \\
\hline Etkinlikler\&Ormanların İşlev.) & & & & & & & & \\
\hline GENEL TOPLAM & 224 & 100.0 & 248 & 100.0 & 152 & 100.0 & 251 & 100.0 \\
\hline
\end{tabular}

* f= frekans değeri, içerik kategori ve unsurlarının metin içinde kaç kez geçtiğini gösterir.

** \%= içerik unsurlarının tüm içerik unsurları toplamına oranını gösterir. 
Tablo 2. "Binali ve Temir", "Divane Ağaç", "Susuz Yaz" ve "Ormanda" eserlerinde orman ve doğa ile ilgili içerik kategorilerinin bulunma şekli.

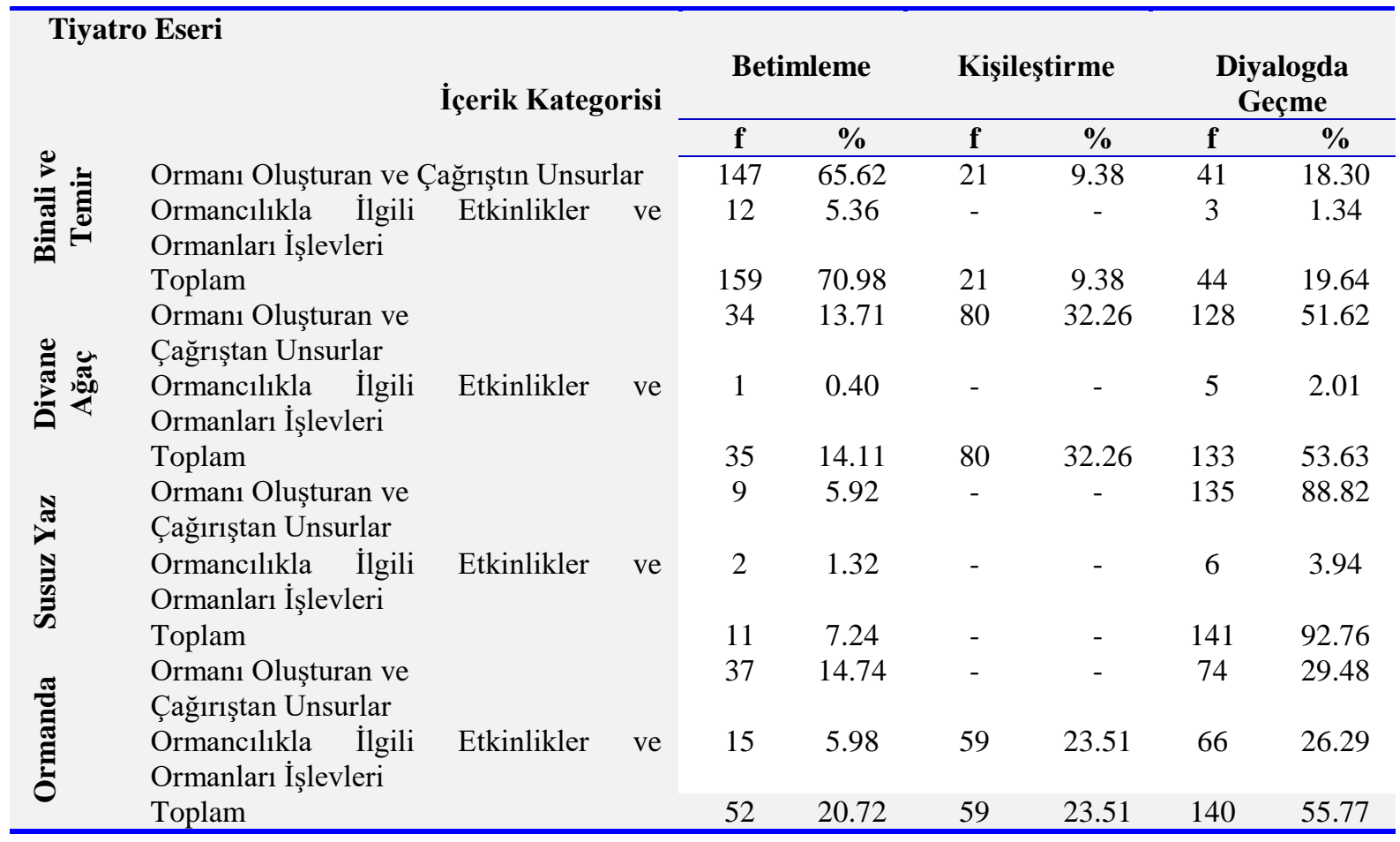

Binali ile Temir eseri toplam 63 sayfadan oluşmaktadır. Eserdeki toplam kelime 14553 olarak belirlenmiştir. Bu kelimelerden 224'ü doğa ve orman ile ilişkilidir. "Binali ve Temir" adlı tiyatro eserinden araştırmaya dahil edilen kategori ve unsurlarla ilgili örnek cümleler Tablo 3'de verilmiştir.

\subsection{Divane Ağaç}

"Divane Ağaç" adlı eserde pek çok (26) unsura ilişkin içerik bulunamamıştır. İçerik unsurlarının bulunma sıklığı incelendiğinde frekansı en yüksek olan ifadenin yaban hayvanı ( $\mathrm{f}=85, \% 34.27)$ olduğu belirlenmiştir. "Ormanı oluşturan ve çağrıştıran unsurlar" kategorisinde ve tüm kategoriler içinde yer alan unsurların metin içinde bulunma sıklığına göre sıralaması ağaç $(\mathrm{f}=67, \% 27.01)$, su $(\mathrm{f}=32, \% 12.9)$, kök $(\mathrm{f}=20, \% 8.06)$, toprak $(\mathrm{f}=16$, \%6.45) ve bitki-çiçek ( $\mathrm{f}=15, \% 6.04)$ şeklinde olmuştur. "Divane Ağaç" adlı eserde "ormancılıkla ilgili etkinlikler ve ormanların işlevleri” kategorisinde yalnızca 2 unsura ilişkin ifade bulunmaktadır. Belirtilen unsurlar yangın ve av/avcılıktır. Bu unsurların da metin içinde bulunma sıklığ 1 düşüktür. Metin içinde yangın unsuruna ilişkin 4, avcılık unsuruna ilişkin 2 ifade yer almaktadır (Tablo 1).

İçerik analizi yapılan Divane Ağaç adlı eserde elde edilen verilerden yola çıkarak doğa ve ormanla ilgili içeriklerin bulunma sıklığının düşük olduğu belirtilebilir. Eser içinde yer alan unsurların büyük çoğunluğunun ( $\mathrm{f}=242, \% 97.59)$ "ormanı oluşturan ve çağrıştıran unsurlar” kapsamında olduğu sonucuna ulaşılmıştır. Metin içinde araştırmaya konu olan unsurların geçtiği yer dikkate alındığında daha çok (f=133, \%53.63) diyaloglarda bulunduğu anlaşılmaktadır. Bunu kişileştirme $(\mathrm{f}=80, \% 32,26)$ ve betimleme $(\mathrm{f}=35, \% 14.11)$ kapsamındaki ifadeler izlemektedir.

$\mathrm{Bu}$ eser tema bakımından kültlerde ve mitlerdeki ağaç simgesi ve tasavvuftaki hayat ağacını konu edindiğinden, ağaç ve hayvan isimleri sıklıkla kullanılmıştır. Divane Ağaç eseri toplam 37 sayfadan oluşmaktadır. Toplam kelime sayısı ise 8332 olarak hesaplanmıştır. Yani 8332 kelime içinde 248 kelime (divane ağaç içerik analizi tablodan) doğa ve orman içeriği ile ilişkili bir anlam taşımaktadır. Divane Ağaç isimli eserde bulunan doğa ve ormana ilişkin unsurları içeren çeşitli ifadeleri barındıran cümle örnekleri Tablo 4'de verilmiştir. 
Tablo 3. Binali ile Temir eserinde içerik unsurlarına ilişkin bazı ifadeler.

\begin{tabular}{|c|c|}
\hline İçerik Unsuru & Metinde Geçen İlgili İfadeler \\
\hline \multicolumn{2}{|c|}{ Ormanı Oluşturan ve Çağrıștıran Unsurlar } \\
\hline Ağaç & Mevsim geçerken bile ulu ağaçların gür yaprakları... \\
\hline Yaban Hayvanı & Onca kekliğin yanına bir de Ceylan katmışım diye göğsüm kabarmadı. \\
\hline Temiz Hava & $\begin{array}{l}\text { Ağaçların, çiçeklerin, sslak otların, kuru yaprakların kokusuna yoğun bir barut } \\
\text { kokusu karışıor. }\end{array}$ \\
\hline Su-Göl-Nehir & Dere incecik bir sızı gibi akıyor. \\
\hline Toprak & Güneş ışınlarının toprağa düşmesine kolay kolay izin vermiyor. \\
\hline Yaprak & Dalından düşen her yeni yaprak bir izi örtüyor. \\
\hline (Doğal) Çevre & $\begin{array}{l}\text { Çöl saatinde her vakte kum yazan bir hançer uçlu ölümdür ova. Dağın } \\
\text { eteklerinden başlar, uzar, sonsuza dek uzar gider. }\end{array}$ \\
\hline Orman (Yolu) & Ormanın mevsimi uzun sürüyor. \\
\hline $\begin{array}{l}\text { Bitki- } \\
\text { Cicek(isimleri) }\end{array}$ & Diken-diken çiçeklenmişti. \\
\hline Bitki Örtüsü & $\begin{array}{l}\text { İlkin bodur ağaçlara, makilere, kırçıl fundalıklara sonra alçak gönüllü ağaçlara } \\
\text { sonra ulu görkemli ağaçlara, gür yapraklara bırakır kendini. }\end{array}$ \\
\hline \multicolumn{2}{|c|}{ Ormancılıkla İlgili Etkinlikler ve Ormanların İşlevleri } \\
\hline $\begin{array}{l}\text { Odun, Kütük, } \\
\text { Yakacak }\end{array}$ & Kalktı ini toparladı, yeniden ot taşıdı, çalı-çırpı, birkaç kütük, ateşi güçlendirdi. \\
\hline Erozyon, Sel, Çı̆ & Sanki ormanı sel basıyor. Dağları yağmur. İçi yıkanıyor. \\
\hline Köylü Halk & Avar onu bulduğunda ölüydü. \\
\hline Odunculuk & $\begin{array}{l}\text { Dalları bir keskiyle ince ince yontmuş, bütün oymacılık hünerini göstermek } \\
\text { istemişti. }\end{array}$ \\
\hline Avcılık & $\begin{array}{l}\text { Bu yüzden mevsim geçerken en zorlu avlar yaşanır. Avcıların gerilmiş } \\
\text { yüreklerindeki bilinmezin/ keklik avına çıktığımız bir gündü. }\end{array}$ \\
\hline
\end{tabular}

Tablo 4. Divane Ağaç eserinde içerik unsurlarına ilişkin bazı ifadeler.

\begin{tabular}{|c|c|}
\hline İçerik Unsuru & Metinde Geçen İlgili İfadeler \\
\hline \multicolumn{2}{|c|}{ Ormanı Oluşturan ve Çağrıştıran Unsurlar } \\
\hline Ăgaç & $\begin{array}{l}\text { Kimileyin o insanoğlu, ağaç olur bana döner, ben olurdu; kimileyin ben ağaç nesli, } \\
\text { insan olup ona döner, o olurdum. Bu kanlı yolda, o yoruldukça bana yaslanır, ben } \\
\text { yoruldukça ona yaslanırdım. Bazen o asa olur, bazen ben insan olurdum. İnsanla } \\
\text { ağaç karışır yürürdük. }\end{array}$ \\
\hline Yaban Hayvanı & $\begin{array}{l}\text { Kimi kartal kanadında semah dönüp diyar-1 ruma, Sakarya suyu kenarına vardılar. / } \\
\text { Doğanı başından kabzasıyla yakaladı. }\end{array}$ \\
\hline Su-Göl-Nehir & Kök olur gah yeraltında suya yürürüz, gah gök yüzünde gövdemizi ararız. \\
\hline Toprak & $\begin{array}{l}\text { Divane Ağaç, sanki on bin yıldır toprağın susuzluğunda doğum sancısına yatmış ta, } \\
\text { yaratanın yardımını çağıran iki canlı bir karabasan gibidir. }\end{array}$ \\
\hline Yaprak & Ben yaprağa durdum, o gölgemde yürüdü. \\
\hline $\begin{array}{l}\text { Bitki- } \\
\text { Cicek(isimleri) }\end{array}$ & Yüreğim güllerde ay izleri bıraktı ey oğul. \\
\hline Bitki Örtüsü & Öyle zaman oldu ki, sonsuzluğun bozkırlarından geçerken, o bana nefes verdi. \\
\hline Kök & Bin yıldır burada köklerimle Yunus’un toprağından himmet alırım. \\
\hline \multicolumn{2}{|c|}{ Ormancılıkla İlgili Etkinlikler ve Ormanların İşlevleri } \\
\hline Yangin & $\begin{array}{l}\text { Her ağacın kovuğunda bir Hz. Zekeriya gizlenir. Benim içime de Hallac gizlendi. } \\
\text { Göz boşluğumdan onu içimde gördüler, sonra da beni, o içimde yansın diye ateşe } \\
\text { verdiler. Aşağıda olup bitenler benim yukarıda yanmamdandı. / Geriye sadece } \\
\text { Divan-1 Ağaç'ın külleri kalır. }\end{array}$ \\
\hline Avcılık & Benim derimi ne bir avcı yüzdü ne de bir aslan pençesi sıyırıp aldı. \\
\hline
\end{tabular}




\subsection{Susuz, Yaz}

Tablo 1'de görüldüğü üzere araştırmaya dahil edilen içerik unsurlarının çoğuna ( $\mathrm{f}=24)$ ilişkin ifadeye metin içinde rastlanmamıştır. Susuz Yaz başlıklı tiyatro eserinin içinde en sık rastlanan unsurun su (göl-nehir vb.) ve ilgili ifadelere $(\mathrm{f}=91, \% 59.86)$ ilişkin olduğu belirlenmiştir. Daha sonra sırasıyla yaban hayvanı $(\mathrm{f}=16, \% 10.52)$, ağaç ( $\mathrm{f}=12, \% 7.89)$, bitki-çiçek $(\mathrm{f}=10, \% 6.58)$, toprak $(\mathrm{f}=7,4.61)$ ve köylü/yerli halk $(\mathrm{f}=6, \% 3.95)$ gelmektedir.

Susuz Yaz adlı eserde içerik analizi sonuçlarına göre orman ve doğaya ilişkin yer alan unsurların büyük çoğunluğu (f=144, \%94.74) "ormanı oluşturan ve çağrıştıran unsurlar" kategorisinde bulunmaktadır. Diğer içerik kategorisi olan "ormancılıkla ilgili etkinlikler ve ormanların işlevleri” kapsamındaki unsurlar içinde köylü ifadesi ( $\mathrm{f}=6, \% 3.95)$ en s1k rastlanan unsur olmuştur. Söz konusu unsurların büyük çoğunluğu (f=141, \%92.76) diyalog içinde yer alırken geri kalanı ( $\mathrm{f}=11, \% 7.24)$ betimlerde geçmektedir (Tablo 2).

$\mathrm{Bu}$ eserin teması bir köyde su kavgası ve yaşanan tartışmalar olduğundan, adından da belli olduğu üzere su kelimesi sıklıkla geçmektedir. Susuz Yaz eseri toplam 68 sayfadan oluşmaktadır. Eserdeki toplam kelime sayısı 12648 olarak belirlenmiştir. Yani 12648 kelimede 152 kelime (susuz yaz içerik analizi tablodan) doğa ve orman içeriği ile ilişkili olarak görülmektedir. İlgili tiyatro eserine orman ve doğaya ilişkin içerik unsurlarını barındıran örnek cümleler Tablo 5'de verilmiştir.

Tablo 5. Susuz Yaz eserinde içerik unsurlarına ilişkin bazı ifadeler.

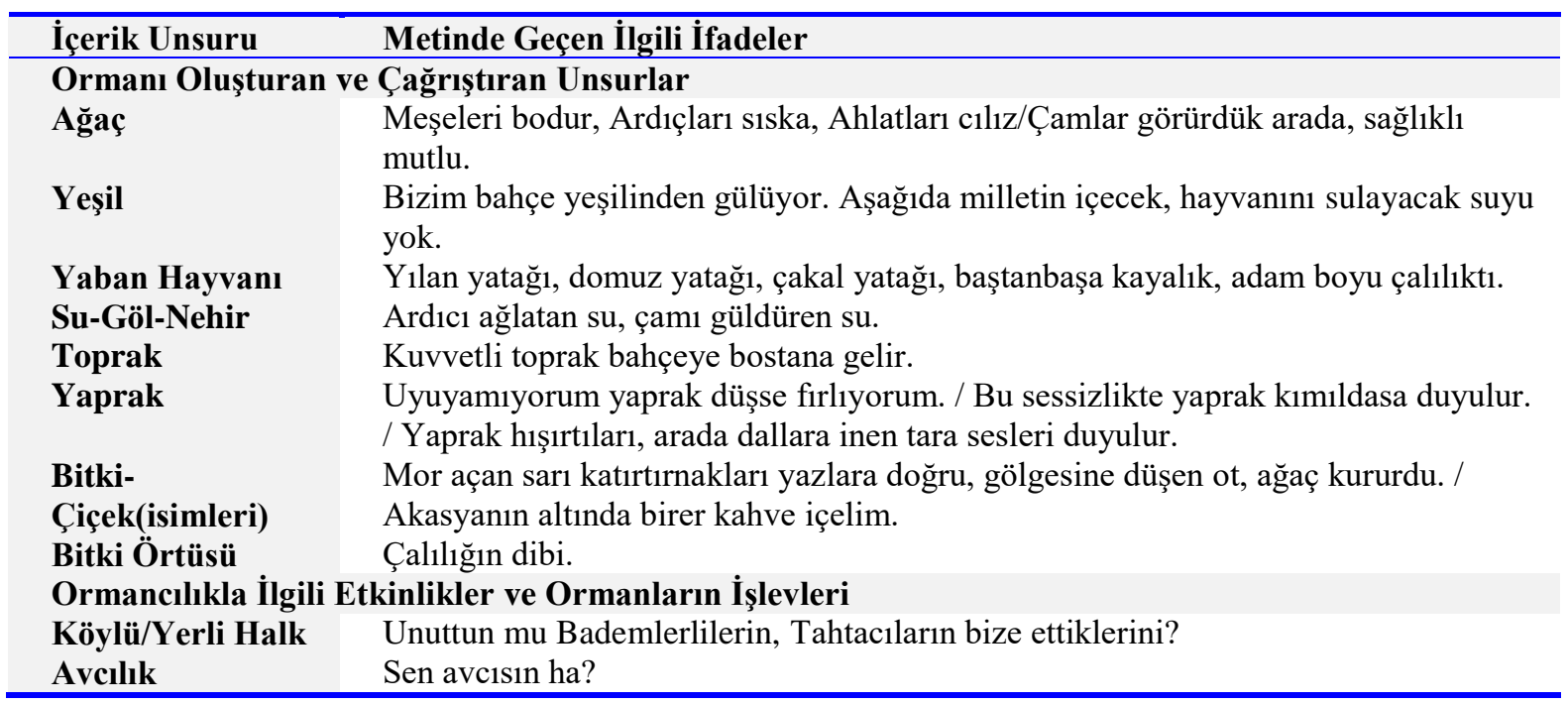

\subsection{Ormanda}

Tablo 1'de görüldüğü üzere çoğu (f=18) unsura ilişkin ifadeye metin içinde rastlanmamıştır. "Ormanda" adlı tiyatro eserinin içinde en sık rastlanan unsurun (doğa) koruma, korucu ( $\mathrm{f}=82, \% 32.67$ ) ve ilgili ifadelere ilişkin olduğu belirlenmiştir. Daha sonra sırasıyla ağaç $(\mathrm{f}=52, \% 20.71)$, orman $(\mathrm{f}=36, \% 14.34)$, kesim-kesmek $(\mathrm{f}=33$, $\% 13.14)$, toprak $(\mathrm{f}=9, \% 3.58)$ ve köylü/yerli halk $(\mathrm{f}=8, \% 3.18)$ gelmektedir.

Ormanda adlı eserde içerik analizi sonuçlarına göre orman ve doğaya ilişkin yer alan unsurların yarısı (f=111, \%44.18) "ormanı oluşturan ve çağrıştıran unsurlar" kategorisinde bulunmaktadır. Diğer içerik kategorisi olan "ormancılıkla ilgili etkinlikler ve ormanların işlevleri” kapsamındaki unsurlar içinde doğa koruma (korucu) ifadesi ( $\mathrm{f}=82, \% 32.66)$ en sık rastlanan olmuştur. Söz konusu unsurların büyük çoğunluğu (f=140, \%55.77) diyalog içinde yer alırken bunu kişileştirme $(\mathrm{f}=59, \% 23.51)$ ve betimleme $(52, \% 20.72)$ kapsamandaki içeriler izlemektedir (Tablo 2).

Ormanda eseri toplam 25 sayfadan oluşmaktadır. Eserde toplam kelime sayısı 5895'dur ve bu kelimelerin 251 'i doğa ve orman içeriği ile ilişkili olarak görülmektedir. İlgili tiyatro eserinde yer alan orman ve doğaya ilişkin içerik unsurlarını barındıran örnek cümleler Tablo 6'da verilmiştir. 
Tablo 6. Ormanda eserinde içerik unsurlarına ilişkin bazı ifadeler.

\begin{tabular}{|c|c|}
\hline İçerik Unsuru & Metinde Geçen İlgili İfadeler \\
\hline \multicolumn{2}{|c|}{ Ormanı Oluşturan ve Çağrıştıran Unsurlar } \\
\hline Ăgaç & On, bilemedin yirmi ağaç devirdin mi, al sana gız gibi tarla. \\
\hline Toprak & Elin oğlu bir garış torpak için adam vuruyo. \\
\hline Orman & Orman yukarılara doğru sıklaşır, kararır, ağar gider. \\
\hline Kök & Önde yer yer kesilmiş ağaç kökleri. \\
\hline Koru & Karaviran goruluğunda ölün galdığında niderik? \\
\hline Yeşil & Orman derik ulan, yeşillik derik. \\
\hline Bitki/Çiçek & Ayrik, acı ot, gara dikenler gelirde aha sonra ben gelirim. \\
\hline \multicolumn{2}{|c|}{ Ormancılıkla İlgili Etkinlikler ve Ormanların İşlevleri } \\
\hline Odun/Kütük & Odun mu? \\
\hline Koruma & Allah vere de gorucu olsun, orman mamuru değel. \\
\hline Köylü & Salmaları kim iletecek köylüye. \\
\hline $\begin{array}{l}\text { Kaçakçılık/Yasa } \\
\text { Dıșı }\end{array}$ & Orman kessin, tarla açsın deyi mi ula? \\
\hline Kesmek & Orman kırar, ağa; keserdi diyeceğim. \\
\hline Kereste & Kereste mi, odun mu, yoğsa keçilere mi? \\
\hline Yangın & Ormanı yakacakdın belkim de, idam. \\
\hline $\begin{array}{l}\text { Odunculuk/Odun } \\
\text { Ürünleri }\end{array}$ & Orman çocuğun beşiği, kapı̆̆ın eşiği, çorbanın kaşığı değel mi? \\
\hline Sürdürülebilirlik & $\begin{array}{l}\text { Kizirin sürüsüne bereket emme ağaç, ağaç gitlaşıyo. Orman tükenir gider. Senin } \\
\text { tohumuna para mı verdiler, Sarılar bir Kizir bulur emme, ya Karaviran korusundan } \\
\text { bu ağaç gidende nolacak. Den bakalım, hadi, suvalime cevap isterim? }\end{array}$ \\
\hline
\end{tabular}

\section{Tartışma ve Sonuç}

Tiyatronun işlevleri tarihi süreçte değişmekte ve günün koşullarına göre şekillenmekle birlikte toplumsal duyarlılık ve bilinç seviyesinin gelişmesine katkısı bulunduğu, eğitici ve yol gösterici bir rolü olduğu genel kabul görmektedir. Bu kapsamda Düz (2010), sanatın ve sanat eğitiminin öncelikli amacının iyi sanat eserlerinin üretilmesinden çok iyi insanlar ve iyi toplumlar yaratılması olduğunu ortaya koymaktadır. Kongar (1976) ise tiyatro eserlerinin başarısını, oyunun vermek istediği mesajı seyirciye doğru iletmesi ve topluma benimsetebilmesi ile mümkün olacağına vurgu yapmaktadır. Bu bakış açıları paralelinde sanatın genel özellikleri dışında tiyatro ile topluma doğa ve ormancılıkla ilgili mesajlar verilebileceği, toplumun doğa ve ormanlarla ilgili bilinç ve duyarlılık seviyesinin tiyatro aracılığıyla yükseltilebileceği belirtilebilir.

Araştırmada elde edilen sonuçlara göre Cumhuriyetten günümüze önemli bir yeri olan şehir tiyatrolarında oynanan ve kabul edilen eserlerin doğa ve ormana ilişkin içerikleri çok sınırlı düzeydedir. Yapılan örneklem çalışmasında İstanbul Şehir Tiyatroları tarafından sahnelenen ve repertuvara alınan 570 yerli ve yetişkin oyunundan uzman görüşleri alınarak, doğa ve ormanla ilgili içeriklerin en yoğun kullanıldığı eserler seçilmesine ve bu kapsamda araştırma yapılmasına karşın söz konusu içeriklerin sayısı ve ilettiği mesajlar toplumda bir farkındalık oluşturabilecek düzeyde olmadığı belirlenmiştir. Ana temanın doğa ve orman olduğu eser sayısının yok denecek kadar az (yapılan araştırmada yalnızca bir oyuna rastlanmıştır) olması da dikkat çekmektedir.

Ana ve yan tema olarak doğa ve ormanın olduğu bir adet oyun tespit edilmekle birlikte diğer eserlerde ancak yer yer oyun içeriklerinde görüldüğü belirlenmiştir. Belirtilen bir oyunun da (Ormanda) yalnızca 1 sezon (19641965) sahnelenmesi dikkat çekmektedir. Ulaşılan bulgular ile örnekleme giren eserlerde doğa ve orman içeriklerinin, çoğunlukla ağaç, su, nehir, kuş, geyik, yaprak gibi ormanı oluşturan ve çağrıştıran unsurlar kategorisinde olduğu belirlenmiştir. Ormancılıkla ilgili etkinlikler ve ormanların işlevleri içerik olarak çok daha az bulunmaktadır.

Araştırmaya konu olan tiyatro eserleri ayrı ayrı incelendiğinde verilen mesajların da önemli bir algı yaratacak düzeyde olmadığı belirtilebilir. "Binali ile Temir”de bir eşkıya ile bir çobanın karşı karşıya gelmesi ve eşkıyanın çobanı rakip görmeye başlaması konu edilmektedir. Oyunun geçtiği mekanlar genelde dağlık ve ormanlık arazilerden oluşmaktadır. Bu çerçevede yapılan betimlemelerde sıkça doğa ve orman ile ilgili ifadeler geçmekle birlikte ormancılık açısından teknik bir durum ortaya konulmamaktadır. Örneğin karakterin, hikayenin bir yerinde "Onca kekliğin yanına bir de Ceylan katmışım diye göğsüm kabarmadı." demesi karşı karaktere göz dağ1 vermek ya da "ceylan" benzetmesi ile küçümsemek olarak değerlendirilebilir. Söz konusu ifade ile avcılıktan söz 
edilmediği açıktır. Yine aynı eserde yer alan başka bir cümle değerlendirildiğinde, "İlkin bodur ağaçlara, makilere, kırçıl fundalıklara sonra alçak gönüllü ağaçlara, sonra ulu görkemli ağaçlara, gür yapraklara bırakır kendini." ifadesi ormancılık açısından değerlendirildiğinde çevrede görülen tür değişimi anlatılmıştır. Ancak hikayenin bütünlüğüne bakıldığında, ilgili anlatımın ölüm betimlenirken kullanıldığı anlaşılmıştır.

Divane Ağaç, tasavvuf temalı bir eser olup, orman ve doğa ile ilgili ifadeler teknik ve bilimsel açıdan bu içerikte ele alınmıştır. Eserde yer alan ilgili ifadeler betimlemeden çok mecazi ve tasavvufi olarak kullanılmaktadır. Örneğin "Her ağacın kovuğunda bir Hz. Zekeriya gizlenir. Benim içime de Hallac gizlendi. Göz boşluğumdan onu içimde gördüler, sonra da beni, o içimde yansın diye ateşe verdiler. Aşağıda olup bitenler benim yukarıda yanmamdandı. Geriye sadece Divanı Ağacın külleri kalır." cümlelerinde teknik olarak yangından söz edilmemekte ruhen yanma kapsamında anlam yüklenmiştir. Yine ağaç ifadesi ile de tasavvuftaki hayat ağacının konu edinildiği belirtilebilir.

Benzer şekilde "Susuz Yaz" eserinde de orman - su ilişkisi teknik boyutu ile ele alınmamakta, sosyal bir çerçevede konu değerlendirilerek, köylülerin su kavgası anlatılmaktadır. Eserde, bir kişinin bahçesinden çıkan suyu, herkese yetecek miktardayken, yalnızca kendi yaralanması için ayırması sonucunda ortaya çıkan çatışma konu edilmektedir. Belirtilen kapsamda metin içerisinde yer yer geçen ağaç isimleri, susuzluk ile ilişkilendirilirken, ormansız alan ile kurak alana ilişskin ifadeler betimlemelerde yer almaktadır. Örneğin, "Meşeleri bodur, ardıçları sıska, ahlatları cılız çamlar görürdük arada, sağlıklı mutlu." cümlesindeki betimleme ile oyunun geçtiği alandaki türlere ilişkin bilgi verilmektedir. "Ardıcı ağlatan su, çamı güldüren su." cümlesi ile ilgili türlerin su ihtiyacına ilişkin bilgi aktarılmakta, yerel halkın bitki türlerine ilişkin bilgisi olduğu da dolaylı olarak ortaya konulmaktadır.

Ormanda eserinde ise incelenen diğer eserlerle karşılaştırıldığında doğrudan ormancılıkla ilişkili konulara daha geniş şekilde yer verildiği görülmektedir. Örneğin, "On bilemedin yirmi ağaç devirdin mi, al sana gız gibi tarla" cümlesinde açıkça orman açmacıllğı ifade edilmektedir. Eserde genel olarak, güçlü olanın ormandan yer açtığı ve ona izin verildiği konu edilmekte, ağanın rahatça ormandan tarla açmasının mümkün olduğu, ancak diğer köylülerin benzer durumda cezalandırıldığı anlatılmaktadır. İlgili dönemin sosyolojik yapısı ve sorunları aktarılırken metin içerisinde "Kizirin sürüsüne bereket emme ağaç, ağaç gitlaşıyo. Orman tükenir gider. Senin tohumuna para mı verdiler, Sarılar bir Kizir bulur emme, ya Karaviran korusundan bu ağaç gidende nolacak. Den bakalım, hadi, sualime cevap isterem." cümlesine yer verilmiştir. $\mathrm{Bu}$ cümle ile ormanın önemi ve sürdürülebilirliği, hatta bir insan hayatından bile önemli olabileceği de vurgulanmakta, ormanların giderek azalmasından bahsedilmekte ve bu durum "sonra bizler ne yaparız" şeklinde sorgulanmaktadır. Aynı zamanda "Orman çocuğun beşiği, kapığın eşiği, çorbanın kaşı̆̆ı değel mi?" sorusuyla orman ürünleri üzerinde durulmaktadır.

Çalışmada yalnızca tiyatro eserlerinin metinleri kapsamında içerik analizi yapılarak bulgular elde edilmiştir. Ancak ulaşılan bulguları daha geniş kapsamlı analiz etmek için, dekor, afiş, kostüm vb. gibi diğer bileşenler üzerinde de araştırma yapılması faydalı olacaktır. Bu bakış açısına paralel olarak May (2005), tiyatronun çevresel unsurlara ilişkin içeriğini değerlendirmek için metinin incelenmesinin yeterli olmadığı bunu sağlamak için oyunun sunumunun yani sahnelenmesinin de dikkate alınması gerektiğini ortaya koymaktadır.

1916'dan günümüze kadar uzanan köklü bir geçmişi olan İstanbul Şehir Tiyatroları, toplumun tiyatro ihtiyacının karşılanması, Türk tiyatrosunun ilerlemesi ve dolaylı olarak da toplumsal gelişimin sağlanması noktasında önemli bir rol üstlenmektedir. Bu durumda ilgili tiyatro topluluğunun doğa ve ormancılık alanında da toplumda bilinç ve farkındalık gelişiminde etkili bir araç olabileceği açıktır. Bu kapsamda doğa ve orman içerikli oyun yazılması ve sahnelenmesi için adım atılması yararlı olacaktır. Benzer bir yaklaşım Hassal ve Rowan (2018) tarafından ortaya konulmakta ve başta iklim değişimi ve sürdürülebilirlik konuları olmak üzere çevre ve doğaya ilişkin konuların tiyatro bölümleri dahil tüm üniversitelerin eğitim programlarında yer alması gerekliliğine işaret edilmektedir. Bununla birlikte gelecek nesil tiyatro metni yazarlarının yetiştirilmesinde sosyal bir sorumluluk olarak ilgili konulara duyarlılı̆ının artırılması gerekliliği üzerinde durulmaktadır (Hassal and Rowan, 2018).

Kuşkusuz bu noktada ormancılıkla ilgili kurumlar ve Orman Fakülteleri ile kurumsal olarak işbirliği yapılması yararlı olacaktır. Bu kapsamda hem tiyatro hem de ormancılık alanında karşılıklı anlama sağlayacak ve ilgiyi uyandıracak uygulamalar geliştirilmelidir. Ormancılı̆̆ın sanat/tiyatro alanlarında etkisiz kaldığı görülmektedir. İlgili alanda belirtilen işbirlikleri kapsamında yarışma, atölye çalışmaları ve etkinlik düzenlemesi önerilebilir. Şehir tiyatrolarının atacağı bu önemli adımlar, ülkenin tiyatro ve sanat anlayışııın gelişmesine katkı sunacağı gibi, tiyatro yazarları ve tüm çalışanlarına, seyircilere, kısacası bir bütün olarak tiyatroya yeni soluklar getireceği öngörülmektedir. Çevreci eleştiri (eko-eleştiri) yaklaşımının Türk tiyatrosuna etkili şekilde yansıması ve bu yolla toplumda farkındalık oluşturabilecek eserlerin yaygınlaşması bakımından da bu uygulamalar olumlu sonuç 
verecektir. May (2007) bu konuda yeni metinlerin yazılması kapsamında drama veya komedi gibi farklı türlerden yararlanılması ile çevresel olarak yaşanan kötü uygulama ve sonuçların ortaya etkili şekilde konulması gerekliliği üzerinde durmaktadır.

Ayrıca sahnelenen oyununun seyirci tarafindan tartışıldığı, seyircinin sahnede yer alarak oyun konusuna ilişkin çözüm önerileri geliştirdiği ve bu yolla konuyu anlama, benimseme ve çözüm üretme kapasitesini destekleyen forum tiyatroların da etkili bir araç olabileceği belirtilebilir. Kuyumcu (2012) tarafından yapılan çalışmada sosyal güvencesi bulunmayan ev işlerinde çalışan kadınlara yönelik yapılan forum tiyatro uygulamasında katılımcıların konuya ilişkin bilinç ve farkındalık düzeyinin geliştiği ortaya konulmuştur. Yine 'Kazdağı Milli Parkı'nda Ekoloji Temelli Doğa Eğitimi”ne katılan öğrencilerin bölgesel düzeydeki efsaneleri canlandırması yönünde bir çalışma yapılmıştır. Söz konusu çalışma ile katılımcıların hem bölgenin tarihi hem de doğal çevreye ilişkin bitki örtüsü ve yaban hayatı gibi bileşenleri hakkında daha kalıcı etkisi olan ve farkındalığı arttırıcı bir deneyim yaşadığı ortaya konulmuştur (Bayındır ve Soykan, 2009). Aynı çalışmada benzer drama tekniklerinin geliştirilmesinin çevre eğitiminin önemli ve etkili bir aracı olabileceği üzerinde durulmuştur.

Diğer taraftan Türk tiyatrosunda, araştırmaya konu olan doğa ve orman içeriklerinin azlığı, ülke, toplum ve birey olarak doğa ve ormana ilginin düşük seviyede olduğunu göstermektedir. Söz konusu ilgi, bilinç ve farkındalığın artması gerekliliği sonucu, Orman Fakültelerinde tiyatro ve sanat dersi, tiyatro, sahne sanatları, dramaturji bölümleri, sinema televizyon bölümleri ve sanatla ilgili tüm bölümlerde de doğa ve orman ile ilgili dersler verilmesi düşünülebilir. Bunun mümkün olmadığı durumlarda seminer, konferans vb. etkinliklerle bütünleşik düşünce ve davranışların başta gençlere ve tüm bireylere kazandırılması mümkün olacaktır. Belirtilen yolla iki kesim de birbirini anlayacak ve tiyatronun doğa ve orman konusunda topluma ulaşmada oynayabileceği potansiyel geliştirilecektir. Belirtilen yaklaşıma paralel olarak May (2007), tiyatroda çevre ile ilgili unsurların yer alması ve eleştirel bir bakış açısının geliştirilmesinin çok disiplinli bir yaklaşım ile sağlanabileceğini ortaya koymaktadir.

Kısacası, doğa ve sanat ihtiyacının bitmeyeceği, daha da çoğalacağı düşünülürse, bu ihtiyaçlara cevap verilebilmesi için, bu etkileşimden tiyatronun ve ormancılığın daha fazla yararlanması gerekmektedir. Tiyatroda doğa ve orman içerikli oyunlar yazılmalı, oynanmalı ve toplumun ilgi göstermesinin sağlanması yönünde çaba harcanmalıdır. Çevresel (eko) eleştiri yaklaşımına paralel olarak ben merkezli değil, doğa merkezli görebilen, yani her şeye insan merkezli değil de tabiat eksenli bakıp, kendisini de tabiatın bir unsuru olarak düşünen insan yapısına tüm dünyanın olduğu gibi Türkiye'nin de ihtiyacı bulunmaktadır. İnsanı insana insanla insanca anlatan tiyatro, hiç şüphesiz doğayı ve ormanları insana anlatma ihtiyacına karşılık verecek etkili bir araç olarak kullanılmalıdır.

\section{Teşekkür}

Bu makale, İstanbul Üniversitesi- Cerrahpaşa, Lisansüstü Eğitim Enstitüsü’nde hazırlanmış olan Yüksek Lisans tez çalışmasının özetidir. Araştırma sürecinde destek olan tüm öğretim elemanları ve İstanbul Şehir Tiyatroları ile İstanbul Devlet Tiyatroları Dramaturgi Birimleri çalışanlarına, ayrıca tez jüri üyesi olarak araştırmaya katkı sağlayan Prof. Dr. Sezgin ÖZDEN ve Doç. Dr. Cihan Erdönmez’e teşekkür ederiz.

\section{Kaynaklar}

1. Ayaz, H. (2014). Çevreci Eleştiri Üzerine Genel Bir Değerlendirme. Uluslararası Türkçe Edebiyat Kültür Ĕ̈itim Dergisi, 3(1), 278-292.

2. Bayındır, A., Soykan, A. (2009). The Role Of Creative Drama İn Comprehending The Legends Environment Related Trainings: Kazdağı Case Study. Procedia Social And Behavioral Sciences 1, 13421348.

3. Düz, N. (2010). Çevrenin Sanatçı Yaratıcılığına Etkileri ve Sanat Eğitimi. Akademik Bakış Dergisi, 19, 115.

4. Güney, A. (2011). Aristoteles ve Bertolt Brecht'nn İngiliz Tiyatrosuna Etkileri. E-Journal of New World Sciences Academy Humanites, 6(1), 135-144.

5. Gürün, D. (2002). Oscar Wilde ve E. G. Craig: Tiyatro Sanatı Üstüne. Ístanbul Üniversitesi Edebiyat Fakültesi Tiyatro Eleştirmenliği ve Dramaturji Bölümü Dergisi, 1, 39-53.

6. Gürün, D. (2009). 1950'ler ve e Tiyatro Sanatının Yönelimleri. Tiyatro Araştırmaları Dergisi, 28(28), 119129. 
7. Heim, W. (2016). Theatre, Conflict and Nature. Green Letters: Studies in Ecocriticism, 20(3), $290-303$.

8. İgit, A. (2017). Yılanların Öcü Filminin Ekoeleştirel Söylem Çözümlemesi. Global Media Journal TR Edition, 7(14), 174-188.

9. Kongar, E. (1976). Toplum Bilim Açısından Tiyatro, Tiyatro Araştırmaları Dergisi, 7(7) 33-43s.

10. Kuyumcu, N. (2012). Halk Eğitiminde "Forum Tiyatro"' Yöntemlerinin Kullanılması. Eğitim ve Öğretim Araştırmaları Dergisi 1(3), 263-267.

11. May, T. (2005). Greening Theatre Studies: Taking Eco-Criticism in Theatre Studies. Theatre Topics, 7(2), 84-103.

12. May, T. (2007). Beyond Bambi: Toward Adonyerous Ecocriticism in Theatre Studies. Theatre Topics, $17(2), 95-110 \mathrm{~s}$.

13. Stemler, S. (2001). An Overview of Content Analysis, Practical Assessment. Research\&Evaluation, 7(1), 1-6.

14. Şen, A. (2018). Bilim Kurgu Sinemasında Ekolojik Adalet ve Ekoeleştiri, İlef Dergisi, 5(1), 31-59s.

15. Temel, T. (2016). Türk Modernleşmesinin Taşıyıcı Gücü: Tiyatro. İdil, 5(26), 1763-1766 .

16. Yılmaz, M. (2017). Genco Erkal ile Tiyatro Üzerine: Röportaj. Şişecam Topluluk Dergisi, 309, 42-43.

17. Yurdakul Erol, S. (2018). Interactions between Forest Policy, Education and Research in Turkey: Policy Documents' and Managers' Perspectives. Baltic Forestry 24(2), 320-331.

18. Yurdakul Erol, S., Şahin, G. (2016). Türkiye'deki Orman Fakültelerinin Stratejik Planlarının Karşılaştırmalı Analizi. İstanbul Üniversitesi Orman Fakültesi Dergisi, 66(2), 497-512.

19. Yurdakul Erol, S., Yıldırım, H. (2017). A Qualitative and Quantitative Analysis of Turkish Forest Policy Documents in The Rural Development Scope. Ciencia Rural,.47 (6),1-9s.

20. Kılıç, D. (2011). Sosyolojik İzlekte Tiyatro-Seyirci İlişkisi Örnek Bir Çalışma Olarak Semaver Kumpanya. Yüksek Lisans Tezi (yayımlanmamış)i İstanbul Kültür Üniversitesi Sosyal Bilimler Enstitüsü, Kültürel İncelemeler Programı, İstanbul, 108s.

21. Berg, B.L., Lune, H. (2015). Sosyal Bilimlerde Nitel Araştırma Yöntemleri. Çeviri Ed: Hasan Aydın, Pearson Eğitim Yayınevi, Konya, 448s.

22. Bilgin, N. (2006). Sosyal Bilimlerde İçerik Analizi Teknikler ve Örnek Çalışmalar, Siyasal Kitabevi, Ankara, 230s.

23. Brecht, B. (1993). Tiyatro İçin Küçük Orgenon, Çeviri: Cemal, A., Tiyatro Kültür Dizisi: 4, Mitos Boyut Yayınları, İstanbul, 120s.

24. Brockett, O., Hildy, F. J. (2017). Tiyatro Tarihi. Mitos Boyut Yayınevi, İstanbul, 688s.

25. Coşkun, R., Altunışık, R., Bayraktaroğlu, S, Yıldırım, E. (2015). Sosyal Bilimlerde Araştırma Yöntemleri: SPSS Uygulamalı., Sakarya Kitabevi, Adapazarı, $381 \mathrm{s.}$

26. Çalışlar, A. (2009). Tiyatronun ABC'si. Say Yayınları, İstanbul,200s.

27. Fuat, M (2010). Tiyatro Tarihi. Mitos Boyut Yayınları, İstanbul, 248s.

28. Gökçe, O. (2006). İçerik Analizi: Kuramsal ve Pratik Bilgiler. Siyasal Kitabevi, Ankara, 136s.

29. Keskin, Y. (2008). Tiyatronun İlkeleri. Doruk Yayınları, İstanbul, 163s..

30. Krippendorff, K. (1980). Content Analysis: An Introduction to Its Methodology. Sage, London, 456s.

31. Nutku, Ö. (1963). Modern Tiyatro Akımları. Dost Yayınları, Ankara, 167 s.

32. Şener, S. (1972). Çağdaş Türk Tiyatrosunda İnsan. Ankara Üniversitesi Dil Tarih Coğrafya Fakültesi Yayınları, Ankara, 159s.

33. Şener, S. (2006). Dünden Bugüne Tiyatro Düşüncesi. Dost Kitabevi, Ankara, 325s.

34. Tunalı, İ. (1995) Aristotales, Poetika. Remzi Kitabevi, İstanbul, 104s.

35. Hassal, L., Rowan, S. (2018). Greening Theatre Landscapes: Developing Susteinable Practice Futures in Theatre Graduates. In University Initiatives in Climate Change Mitigation and Adaptation Ed. Leal Filho, W., Leal-Arcas, R., Springer, pp.143-158.

36. Prasad, B.D. (2008). Content Analysis: A Method in Social Science Research. In Research Methods For Social Work Ed Bhaskaran Lal Das, D., Rawat Publications, pp 173-193. 